\title{
About borders and limits: experiences with UNESCO Biosphere Reserves for trans- boundary cooperation in Ukraine and neighbouring countries
}

\author{
Pierre L. Ibisch, Angela Dichte, Fedir D. Hamor, Andrii Holovko, Vasyl F. Pokynchereda, Mykola P. Rybak \& \\ Iuliia Shvediuk
}

Keywords: biosphere reserves, Eastern Europe, Ukraine, transboundary cooperation

\section{Abstract}

In Eastern Europe, several UNESCO Biosphere Reserves (BRs) have been important promoters of transnational and transboundary nature conservation and sustainable development. Nevertheless, political and institutional barriers and scarcity of resources have hindered successful cross-border cooperation. The prospects for BRs in Eastern Europe are mixed, especially in relation to the challenges of ecosystem degradation and climate change, as well as socioeconomic and (geo)political crises. Based on our own experience of one and a half decades of growing cooperation between partners in Ukraine and Germany, we conclude that transnational cooperation between BRs and science is particularly rewarding and mutually beneficial.

\section{Introduction}

Many protected areas and biosphere reserves (BRs) are located along political borders, which are often drawn through less densely populated areas such as mountainous regions or larger forest areas, or follow ecologically relevant systems such as river courses (Westing 1998; Fall 2003). This predestined BRs to be motors of cross-border cooperation. In 1995, the Seville Strategy was launched, which included recommendations for the world network of BRs (UNESCO 1996). In 2000, the Seville+5 meeting was held in Pamplona, Spain. The so-called Pamplona Recommendations explicitly addressed the establishment of Transboundary Biosphere Reserves (TBRs) as a new framework for international conservation (Fall 1999).

However, few studies so far have investigated the extent to which TBRs have really succeeded in initiating a new quality of cross-border cooperation in nature conservation and sustainable development, and the studies' results show a mixed picture (e.g. Stein 2008; Taggart-Hodge \& Schoon 2016; Trillo-Santamaria \& Pauel 2016; Romano et al. 2020; Weber \& Weber 2020). The main obstacles are found in the various institutional, legal and historical development processes, which have not yet been used as learning opportunities (Romano et al 2020). Moreover, too much emphasis is often placed on gaining international recognition, the development of tourism, and the acquisition of funding (Trillo-Santamaria \& Pauel 2016), instead of on endogenous development towards sustainable practices in collaboration with local stakeholders (Romano et al. 2020). Overall, it appears that effective management is not the automatic consequence of establishing a TBR, and that more research on interrelations between the legal conditions, governance structures, and knowledge management is needed. Eastern Europe seems to be a particularly suitable region for the investigation of such issues.
After the break-up of the Soviet Union and the Cold War, the successor states, such as Ukraine and its neighbouring countries, generally tied in with previous nature conservation efforts, but they also endeavoured to test and use multilateral and international formats of cooperation in the midst of a spirit of optimism shaped by the new global environmental agreements, such as the Convention on Biological Diversity. While many Eastern European countries such as Poland or Romania were given the chance to associate with Western European countries, Ukraine suddenly found itself in a new kind of border situation - some actors perceived the border with the European Union as a kind of new Iron Curtain. Accordingly, nature conservation actors, especially in western Ukraine, made efforts to systematically link up with partners in neighbouring countries, such as Romania, Slovakia, and Poland. This included the development and expansion of BRs as well as the establishment of UNESCO World Heritage sites, or regional environmental agreements such as the Carpathian Convention.

\section{Transnational and transboundary conser- vation promoted by biosphere reserves: mixed experiences and lessons learned}

In post-Soviet countries, the designation as a UNESCO BR was often seen as an international recognition of, or even an award for, outstanding natural features - more in the sense of a UNESCO World Natural Heritage Site. At the same time, it is often observed that BRs are essentially seen as instruments of nature conservation and less as model regions, or even laboratories, for sustainable development (e.g. Těšitel \& Kušová 2020). It is also problematic that BRs are not, as the MAB programme's goals would wish, anchored in national legislation. Normally, there is no additional budget to meet the obligations associated with BR status and the activities that would distinguish the areas from ordinary protected areas. At the same 


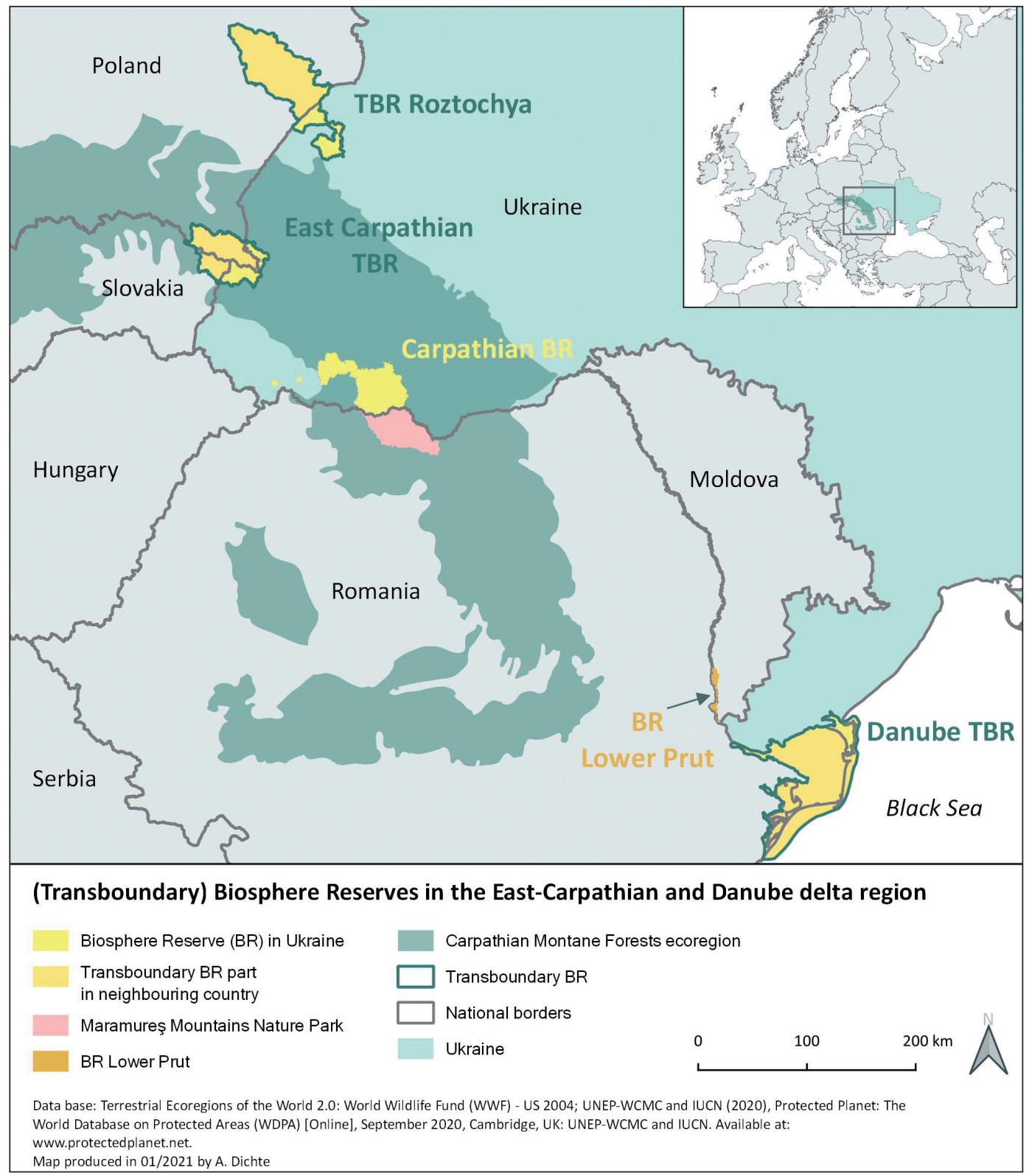

Figure 1 - (Transboundary) biosphere reserves in the East-Carpathian and Danube delta region.

time, demands and expectations regarding modern management of BRs have been growing, including participatory approaches (compare Geyer et al. 2009) and integrated management of complexly zoned territories, where frequent conflicts of interest have to be mitigated (Ibisch et al. 2011).

Nevertheless, even in the most difficult times of economic and political crises, some BRs demonstrated creativity and great commitment and became the driving force of international processes. For instance, from the 1990s onwards, protected areas in Ukraine and Slovakia, including the Carpathian Biosphere Reserve (CBR), discussed whether their old growth and primeval beech forests could be considered for nomination as UNESCO World Natural Heritage sites (Britz et al. 2009; Vološčuk et al. 2013; Ibisch et al. 2017). The importance of these unique wilderness areas was presented at international level and recognized in 2007 by the inclusion of 10 component parts of a transnational site in Ukraine and Slovakia in the UNESCO World Natural Heritage programme. Intensive exchanges between German and Ukrainian partners resulted in the addition of 5 more sites in Germany in 2011 (Knapp 2013). This in turn led to a pan-European screening process in 2017 and the inclusion of a further 63 sub-areas in 9 more countries, thus creating a more complete picture of the postglacial expansion processes of beech forests in Europe within the serial World Heritage Site Ancient and Primeval Beech Forests of the Carpathians and Other Regions of Europe (Ibisch et al. 2017). In 2021, further areas in 8 additional countries were added. This outstanding example of transnational cooperation is based on the work and commitment of many people, but a pivotal force in this process has been and still is the CBR, which comprises several component parts of the serial Site, including the single 
Table 1 - Exchanges between UNESCO Biosphere Reserves and academic partners from Germany and Eastern Europe: timeline of selected cooperation activities between the Centre for Econics and Ecosystem Management (CEEM) at Eberswalde University for Sustainable Development (EUSD) and the Ukrainian partner institutions Carpathian Biosphere Reserve (CBR) and Ukrainian National Forestry University (UNFU).

\begin{tabular}{|c|c|}
\hline Year & Milestone \\
\hline 2005 & First visit of students from EUSD to the CBR (motivated by Swiss-Ukrainian travel guide) \\
\hline Since 2006 & $\begin{array}{l}\text { Integration of annual visits to CBR in context of delivering modules on biosphere reserves, ecosystem and natural resources } \\
\text { management in transformation countries (such as the post-Soviet states) (Bachelor's and Master's programmes: International } \\
\text { Forest Ecosystem Management, Global Change Management) }\end{array}$ \\
\hline 2008 & Memorandum of Understanding for cooperation between EUSD and CBR \\
\hline 2009-2011 & $\begin{array}{l}\text { German Environment Foundation (DBU)-funded project between CEEM/EUSD and CBR for the development of a new man- } \\
\text { agement concept for the CBR; joint book publication }\end{array}$ \\
\hline Since 2010 & $\begin{array}{l}\text { EUSD and CBR cooperation related to the extension and management of the UNESCO World Heritage site dedicated to pri- } \\
\text { meval and ancient beech forests (projects funded by the German Ministry for Environment, Nature Conservation and Nuclear } \\
\text { Safety) }\end{array}$ \\
\hline 2012-2014 & $\begin{array}{l}\text { European World Heritage Beech Forests Research and development project implemented by EUSD with CBR, funded by the } \\
\text { German Ministry for Environment, Nature Conservation and Nuclear Safety }\end{array}$ \\
\hline Since 2014 & $\begin{array}{l}\text { Involvement of Ukrainian National Forestry University (UNFU) and Roztochya Biosphere Reserve in annual student excursions } \\
\text { to biosphere reserves, joint student symposia, and exchanges of students and staff }\end{array}$ \\
\hline 2016 & $\begin{array}{l}\text { German Academic Exchange Service (DAAD) project on the involvement of civil society in sustainable forest management in } \\
\text { the Ukrainian Carpathians (EUSD, CBR, UNFU) } \\
\text { Round table in Ukraine on anniversary of Man and the Biosphere programme (incl. Lima Action Plan) }\end{array}$ \\
\hline Since 2016 & Erasmus + projects between EUSD, UNFU and CBR for student and staff mobility \\
\hline 2017 & $\begin{array}{l}\text { DAAD project on transboundary cooperation for ecosystem-based sustainable development with partners from Moldova, } \\
\text { Romania and Ukraine }\end{array}$ \\
\hline 2018 & DAAD project on biosphere reserves and ecosystem services with partners from Moldova, Romania and Ukraine \\
\hline 2018-2021 & $\begin{array}{l}\text { Project on ecosystem-based adaptation to climate change in and with Ukrainian biosphere reserves (funded in the framework } \\
\text { of the International Climate Initiative) }\end{array}$ \\
\hline 2019 & $\begin{array}{l}\text { DAAD project on biosphere reserves and transboundary cooperation with partners from Moldova, Romania and Ukraine, } \\
\text { including a study trip and summer school with BR representatives and students from Germany, Ukraine and Moldova in Lower } \\
\text { Prut Biosphere Reserve, Moldova }\end{array}$ \\
\hline 2020 & DAAD project on Eastern Europe in a VUCA* world with partners from Moldova, Romania, Ukraine and Germany \\
\hline Since 2020 & Erasmus+ project between EUSD and Moldovan State University for student and staff mobility \\
\hline 2021 & DAAD project on biosphere reserves and forests with partners from Ukraine, Moldova and Germany \\
\hline
\end{tabular}

*characterized by Volatility, Uncertainty, Complexity and Ambiguity (Scbick et al. 2017)

largest one of the now truly pan-European property. As well as the CBR, two other Ukrainian BRs, also located in transboundary regions, contribute component parts to the serial World Heritage Site: Roztochya BR and the trilateral Eastern Carpathians Transboundary Biosphere (ECTB).

The ECTB, comprising protected areas in Poland, Slovakia and Ukraine, is the East-European pioneer for transboundary conservation involving BRs (see Taggart-Hodge \& Schoon 2016). Established as early as 1998, currently it is an example of a paper BR, which is suffering from a lack of resources; it does not dispose of a central office, a common management regime, or any active coordination. Nevertheless, it was a natural aspiration of the CBR, which had successfully strengthened itself in international cooperation, to try to reach out to protected areas beyond the national border and to strive to establish a TBR in the Maramarosh region in northern Romania and southwestern Ukraine. Not only do the same ecosystems extend over the borders between Ukraine and Romania, but the region also comprises important ecological migration routes for large predators such as brown bears. In addition, in the course of the region's dynamic history, ethnic minorities such as the Hutsuls, who are intimately connected with particular ecosystems, were forced into two different national territories (Romania and Ukraine) after World War I. The natural candidate for formal transboundary cooperation would be the Maramureș Mountains Nature Park in Romania (see Figure 1). The topic of a potential TBR was raised after CBR obtained its status as a UNESCO BR, and was included in the Strategy for the implementation of the Carpathian Convention, as well as adopted at the level of the Ukrainian Cabinet of Ministers in 2007. A largescale EU project was carried out in the Carpathians (BioRegio, 2011-2014), targeting the establishment of a TBR in the Maramarosh region, but unfortunately the Romanian partners could not achieve the nomination as a UNESCO BR as they lacked the approval of local communities, who saw an international BR as a threat to their development aspirations.

More than a decade ago, Bihun et al. (2008) stated: "In practice transboundary cooperation in the management of Ukraine's protected areas is informal, fragmentary, and poorly planned." We feel that substantial progress has been achieved, at least in some areas. Nevertheless, establishing and maintaining effective TBRs in Eastern Europe remains challenging.

In a decade and a half of growing cooperation between partners in Ukraine and Germany, including the CBR in Transcarpathia, the Eberswalde University for Sustainable Development (EUSD) and the Ukrainian National Forestry University in Lviv (UNFU), we have 
experienced cooperation between BRs and academia as particularly rewarding and mutually beneficial. In the context of annual study trips since 2005 and other projects, the potential of BRs in Ukraine and adjacent regions is analysed on a regular basis (see Table 1). Every year since 2016, EUSD together with CBR and UNFU have been conducting year-long projects, which are supported by the German Academic Exchange Service (DAAD). In 2017, the framework was extended to include partners from Moldova and Romania, and the focus on involving civil society in ecosystem management was enriched by the topic of cross-border cooperation. In our experience, academia and BRs can jointly initiate thematic and regional networks and successfully combine transnational education, research and development. Academic ambitions and teaching activities can help to put particular topics on the BRs' agendas, and to foster dialogue across sites.

\section{Prospects}

The need for Eastern European BRs that can show the way to sustainable development and peace-building transboundary cooperation is greater than ever. At the same time, the framework conditions are not always improving. In the midst of a crisis of multilateralism, the geopolitical situation (for example in Ukraine) between a weakened European Union and an unpredictable Russian Federation remains extremely difficult (see e.g. Allison 2014, Sanders \& Tuck 2020). The BRs have also been catapulted into a world characterized by increased Volatility, Uncertainty, Complexity and Ambiguity (VUCA) (Schick et al. 2017). Not only are further unforeseeable economic and political crises or ruptures to be expected in a region which has long been subject to these, but climate-change-related weather extremes, and dramatic changes in ecosystems and ecosystem services can also be anticipated, which may in turn contribute to emergency situations and further over-exploitation of natural resources. Unfortunately, in the last decade, earlier worst-case scenarios have come true or been exceeded by reality. For example, Geyer et al. (2010) stated that "Development will increase the pace of forest exploitation including old growth forests and forests in protected areas as a result of better access, weak law enforcement and a lack of funds for conservation and forestry management", and that "Climate change also causes increased drought stress to forest ecosystems such as spruce stands, resulting in possible mass die-offs facilitated by bark beetle infestation."

Consequently, to fully embrace the function of model sites for ecosystem-based sustainable development and to act as change agents through transboundary cooperation, state and regional policies and legislation will have to be revised in compliance with the strategic Lima Action Plan, which was endorsed for the World Network of Biosphere Reserves in 2016. (T)BRs as legal entities need to be strengthened and equipped with distinct competencies that set them apart from other protected areas. In times of global and national crises, they can play a role in developing ecosystem-based safety nets (for example by securing the delivery of ecosystem services like food and climate regulation) for the local populations (Geyer et al. 2010). Adequate political and stakeholder support as well as legal backing and law enforcement are necessary, as well as alliances between BRs and academia.

\section{References}

Allison, R. 2014. Russian 'deniable' intervention in Ukraine: how and why Russia broke the rules. International Affairs 90(6): 1255-1297. Oxford, Malden. Available at: https://ora.ox.ac.uk/objects/ uuid:d8750c28-482d-427f-8354-20dcac606ad6/ download_file?safe_filename=INTA90_6_01Allison. pdf\&file_format=application $\% 2$ Fpdf\&type_of_ work=Journal+article (accessed: 23/08/2021)

Bihun, Y.M., W.S. Keeton, O. Stankiewicz \& M. Ceroni 2008. Transboundary Protected Areas Cooperation in the East Carpathian and Carpathian Biosphere Reserves. Report Project No UA0004.1, WWF. Wien. Available at: http://www.uvm.edu/rsenr/wkeeton/pubpdfs/ BihunKeetonStankiewiczCeroni2008ReportWWF. pdf (accessed: 23/08/2021)

Britz, H., O. Dieckmann, B. Engels, A. Frede, T. Geisel, M. Großmann, K. Kaiser, H.D. Knapp, M.E. Luthardt \& J. Seuring (eds.) 2009. Nomination of the " $A n$ cient Beech Forests of Germany" as Extension to the World Natural Heritage "Primeval Beech Forests of the Carpathians" (1133) - Nomination Dossier to UNESCO for Inscription on the World Heritage List. 504 ff. Available at: https://whc.unesco.org/uploads/nominations/1133bis. pdf (accessed: 23/08/2021)

Fall, J. 1999. Transboundary biosphere reserves: a new framework for cooperation. Environmental Conservation 26(4): 252-255.

Fall, J. 2003. Planning Protected Areas Across Boundaries. Journal of Sustainable Forestry 17(1-2): 81102. Doi: 10.1300/J091v17n01_06

Geyer, J., F.D. Hamor \& P.L. Ibisch 2009. Carpathian biosphere reserve (Ukraine): towards participatory management. eco.mont - Journal on Protected Mountain Areas Research 1(2): 5-12. Doi: 10.1553/ecomont2s5

Geyer, J., L. Schmidt, I. Kruglov, V. Gubko, P.C. Sandei \& P.L. Ibisch 2010. Development, biodiversity conservation and global change in the Ukrainian Carpathians. In: Ibisch, P.L., A. Vega E. \& T.M. Herrmann (eds.), Interdependence of biodiversity and development under global change. Technical Series No. 54. Secretariat of the Convention on Biological Diversity: 82-96. Montreal. Available at: https://www.cbd.int/doc/publications/ cbd-ts-54-en.pdf (accessed: 23/08/2021)

Ibisch, P.L., J. Geyer, L. Schmidt, V. Pokynchereda \& V. Gubko (eds.) 2011. Carpathian Biosphere Reserve: challenges and solutions for protected area management in Ukrainian Transcarpathia. Aachen. 
Ibisch, P.L., M.G. Waldherr \& H.D. Knapp 2017. Erweiterungsnominierung zu den „Buchenurwäldern der Karpaten und Alten Buchenwäldern Deutschlands“ als paneuropäische UNESCO-Weltnaturerbestätte (Extension nomination to the „Primeval Beech Forests of the Carpathians and Ancient Beech Forests of Germany" towards a pan-European World Heritage Property). Natur und Landschaft 92(3): 109_ 118.

Knapp, H.D. 2013. Alte Buchenwälder Deutschlands - UNESCO Weltnaturerbe. In: Succow, M., L. Jeschke \& H.D. Knapp (eds.), Naturschutr. in Deutschland: Rückblicke-Einblicke-Ausblicke (2 ${ }^{\text {nd }}$ ed.): 289-295. Berlin.

Romano, J., E. Pérez-Chinarro \& B.V. Coral 2020. Network of Landscapes in the Sustainable Management of Transboundary Biosphere Reserves. Land 9(9): 320. Doi: 10.3390/land9090320

Sanders, D. \& C. Tuck 2020. The Ukraine Conflict and the Problems of War Termination. The Journal of Slavic Military Studies 33(1): 22-43. Doi: 10.1080/13518046.2020.1723219

Schick, A., P.R. Hobson \& P.L. Ibisch 2017. Conservation and sustainable development in a VUCA world: the need for a systemic, risk-robust and ecosystem-based approach. Ecosystem Health and Sustainability 3(4): e01267. Doi: 10.1002/ehs2.1267

Stein, R. 2008. The Pfälzerwald-Vosges du Nord transboundary biosphere reserve. International Journal of Environment and Sustainable Development 7(2): 156169. Doi: 10.1504/IJESD.2008.018361

Taggart-Hodge, T.D. \& M. Schoon 2016. The challenges and opportunities of transboundary cooperation through the lens of the East Carpathians Biosphere Reserve. Ecology and Society 21(4): 29. Doi: 10.5751/ES-08669-210429

Těšitel, J. \& D. Kušová 2020. The more institutional models, the more challenges - Biosphere reserves in the Czech Republic. In: Reed, M.G. \& M.F. Price (eds.), UNESCO Biosphere Reserves - Supporting Biocultural Diversity, Sustainability and Society. Earthscan Studies in Natural Resource Management: 125-134.

Trillo-Santamaria, J.M. \& V. Pauel 2016. Transboundary protected areas as ideal tools? Analyzing the Gerês-Xurés transboundary biosphere reserve. Land Use Policy 52: 454-463. Doi: 10.1016/j.landusepol.2015.12.019

UNESCO 1996. Biosphere reserves: The Seville Strategy and the Statutory Framework of the World Network. UNESCO, Paris

Vološčuk, I., V. Pichler \& M. Pichlerova 2013. The Primeval Beech Forests of the Carpathians and Ancient Beech Forests of Germany: Joint natural Heritage of Europe. Folia Oecologica 40(2): 295-303.

Weber, F. \& F. Weber 2020. Grenzen überwinden - Herausforderungen und Potenziale bei der Weiterentwicklung des Biosphärenreservates PfälzerwaldNordvogesen. In: Bosdorf, A., M. Jungmeier, V. Braun \& K. Heinrich (eds.), Biosphäre 4.0. UNESCO Biosphere
Reserves als Modellregionen einer nachhaltigen Entwicklung: 227-238. Berlin, Heidelberg.

Westing, A.H. 1998. Establishment and management of transfrontier reserves for conflict prevention and confidence building. Environmental Conservation 25(2): 91-94.

\section{Authors}

\section{Pierre Ibisch}

is Professor for Nature Conservation and Research Professor for Ecosystem-based Sustainable Development, Faculty for Forest and Environment, Eberswalde University for Sustainable Development. He is also the founding director of the Centre for Econics and Ecosystem Management, one of the scientific directors of the Biosphere Reserves Institute, and Vice Chair of Deutsche Umweltstiftung. His main areas of expertise include sustainable development, nature conservation, and the management of (forest) ecosystems under climate change. Eberswalde University for Sustainable Development, Germany, Alfred-Möller Str. 1, 16225 Eberswalde, Germany. E-mail: pierre. ibisch@hnee.de

\section{Angela Dichte - corresponding author}

is project assistant at the Centre for Econics and Ecosystem Management, Eberswalde University for Sustainable Development. She is also a student on the Biosphere Reserves Management Master's course in Eberswalde. Her main areas of work are: exchanges between academia, civil society and Biosphere Reserves in Eastern Europe; ecosystem-based climate change adaptation. Eberswalde University for Sustainable Development, Germany, Alfred-Möller Str. 1, 16225 Eberswalde, Germany. E-mail: angela.dichte@ hnee.de

\section{Fedir D. Hamor}

was a key figure in the development of the Ukrainian Carpathian Biosphere Reserve (1987-2013), of which he was also the Director. He initiated the inclusion of European beech virgin forests in the UNESCO World Natural Heritage List. E-mail: fhamor@ ukr.net

\section{Andrii Holovko}

holds a Master's degree in Management, a specialist degree in Forestry, and a PhD in environmental economics. He is head of the Department of Management of Organizations and Administration, Ukrainian National Forestry University, and a forest management auditor. His research interests are forestry economics and forest policy. Ukrainian National Forestry University, Ukraine, Gen. Chuprynky str. 103, 79057 Lviv, Ukraine. E-mail: golovko_andriy@nltu.edu.ua 


\section{Vasyl F. Pokynchereda}

is the deputy head of the Department for Scientific Research and International Cooperation at the Carpathian Biosphere Reserve. He played a leading role in the creation and extension of the transnational UNESCO World Natural Heritage site of European beech forests and is a member of the Natural Heritage Sector of the National Commission of Ukraine for UNESCO. Carpathian Biosphere Reserve, Ukraine, Krasne Pleso str. 77, 90600 Rakhiv, Ukraine. E-mail: pokynchereda@ukr.net

Mykola P. Rybak

was the acting director of the Carpathian Biosphere Reserve, where he has worked for 37 years. He trained in forestry and as an environmental engineer, and is a member of the national steering group of the transna- tional UNESCO World ritage Site Ancient and Primeval Beech Forests of the Carpathians and other Regions of Europe. Carpathian Biosphere Reserve, Ukraine, Krasne Pleso str. 77, 90600 Rakhiv, Ukraine. E-mail: mykola. rakhiv@gmail.com

Iuliia Shvediuk

has a $\mathrm{PhD}$ in Economics and is a lecturer at the Department of Management of Organizations and Administration, Institute of Environmental Economics and Management, Ukrainian National Forestry University, Lviv, Ukraine. Her research areas are forestry decision making, recreational management, environmental and economic efficiency, and forest policy. Ukrainian National Forestry University, Ukraine, Gen. Chuprynky str. 103, 79057 Lviv, Ukraine. E-mail: shvediukiuliia@nltu.edu.ua 